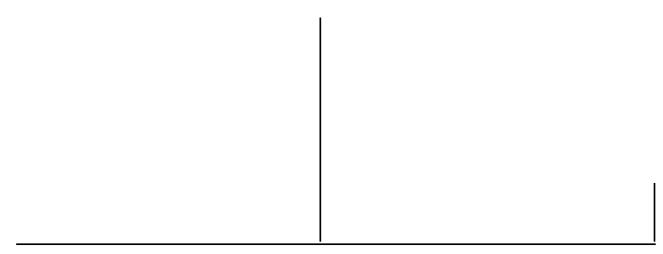

Rev. Latinoam. Psicopat. Fund., VI, 2, 69-88

\title{
A ética: uma renovação da clínica nas práticas de saúde?*
}

\author{
Roland Gori \\ Marie-José Del Volgo
}

A utilização do conceito de ética no campo da saúde pode ser deduzido da necessidade de se levar em conta um resto produzido pelas novas tecnologias discursivas que tratam, em nossa época, da saúde, da doença e seu tratamento.

Os progressos espetaculares dos procedimentos tecnocientíficos da medicina, longe de reduzir o alcance do ato de avaliação, amplificam dialeticamente aquilo que neles encontra-se em jogo.

Palavras-chave: Ética, práticas de saúde, medicina tecnocientífica

* Tradução de Marta Gambini. 
Em matéria de patologia, a primeira palavra, historicamente falando, e a última palavra, logicamente falando, cabe à clínica.

G. Canguilhem, Le normal et le pathologique, p. 153.

E então, qual é o tipo de sociedade, dispondo de uma organização sanitária que explora a mais sofisticada informação sobre a distribuição e as correlações dos fatores de doenças, que dispensará um dia o médico da tarefa, talvez desesperada, de sustentar indivíduos desamparados em sua luta ansiosa por uma cura aleatória? G. Canguilhem, Écrits sur la médecine, p. 88, sublinhado por nós.

\section{A ética: um resto de escolhas metodológicas?}

Em nossa cultura recorre-se tanto à ética, que isso por vezes soa como encantação proferida por retóricas e ideologias pouco rigorosas com as exigências conceituais da filosofia moral (cf. Canto-Sperber, 2001). Se tudo é ética, então mais nada mais o é. Assim, seria conveniente em primeiro lugar determinar e tornar mais claro seu uso, ou seja, sua significação, em nossa análise dos discursos e das práticas da saúde. A utilização do conceito de ética no campo da saúde ${ }^{1}$ pode ser deduzido da necessidade de se levar em conta um resto produzido pelas novas tecnologias discursivas que tratam, em nossa época, da saúde, da doença e seu tratamento. Ao ponto que, atualmente, diante da profileração das técnicas médicas e de suas consequiências para o paciente enquanto indivíduo, mas também enquanto representante do humano, uma nova profissão acabou nascendo nos países anglo-saxões: a de "bioético". Esses bioéticos têm por missão esclarecer as equipes de cuidadores sobre o que está em jogo em termos éticos nas suas decisões práticas. Jacqueline Lagrée (2002) lembra que o termo "bioético" foi inventado em 1970 por um biólogo americano, especialista em câncer, Van Rensselear Potter. A bioética diz respeito, em primeiro lugar, à ética necessária à sobrevivência do homem, e depois, de modo mais geral, às condições da vida na terra. Foi só em seguida que ela começou

1. Por comodidade verbal reagruparemos neste artigo sob o termo "saúde" as questões referentes à doença, a seu tratamento e à prevenção. 


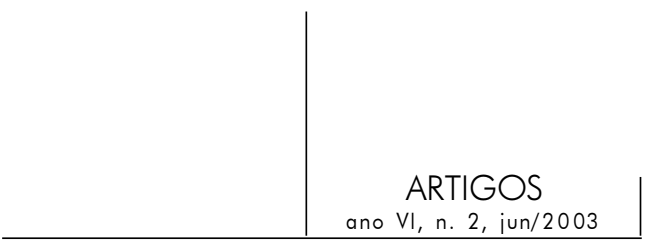

a designar a reflexão sobre o que se encontra eticamente em jogo nas novas técnicas biomédicas, reatando assim com a tradição de uma ética médica exigindo que os pacientes sejam tratados de acordo com as regras específicas da arte médica. Não se trata mais somente de verificar se o procedimento experimental próprio à lógica científica foi bem cumprido, mas, mais rigorosamente, de exigir que o humano seja respeitado nessas práticas. Deve-se notar que esse imperativo ético de ter que se respeitar o humano em sua especificidade toma ao menos duas vias. A primeira é a da definição de um quadro legislativo, portanto relativo a uma certa cultura num dado momento, capaz de limitar a experimentação no homem, recusando sua instrumentalização em benefício da ciência. A segunda via é a de uma ética, exigindo que cada caso seja tratado como um caso singular levando-se em conta as circunstâncias particulares das práticas de diagnóstico, de tratamento e de experimentação na mais pura tradição médica.

A primeira via é bem conhecida, tendo sido bem explorada e dando ensejo a importantes debates públicos amplamente midiatizados. De fato, se a experimentação no homem mostra-se indispensável para os progressos do saber médico sobre a doença e seus tratamentos, convém enquadrar rigorosamente a prática, insistindo sempre mais sobre a primazia da finalidade terapêutica e evitando derivações, tendo-se sempre em mente as loucuras criminosas dos médicos nazistas. Desde sempre, a experimentação humana tanto em cirurgia quanto em medicina, consistiu em se provocar um certo fenômeno para estudar seus efeitos. Antigamente, esse tipo de experiência era praticada nos condenados à morte, nos doentes incuráveis e nos prisioneiros. Sabemos que, entre outros, o código de Nuremberg de 1947, a declaração de Helsinki em 1964 e as declarações posteriores sobre a proteção do humano e a recusa de instrumentalizar seu corpo, progrediram todos insistindo sempre mais na necessidade do consentimento esclarecido e do direito do paciente de interromper sua participação na experiência desde que essa intenção fosse manifestada. A lei Huriet de 1988, a convenção européia de bioética de 1994 e o código de deontologia médica de 1995 inspiraram-se diversamente nesses princípios gerais de respeito à pessoa humana, o que em seguida gerou um debate infindável sobre o que se entendia por "respeito" e por "pessoa humana". Os atuais debates sobre a clonagem ou sobre o estatuto do embrião fazem parte dessa reflexão ética. Não é essa a via que vai nos interessar prioritariamente aqui, mesmo que por vezes sejamos levados a nos referir a ela.

A outra via a ser seguida quando se trata de ética médica, e até mesmo de modo mais geral de práticas de saúde, consiste em reconhecer que o doente não poderia ser reduzido ao estatuto de portador de uma doença, que não poderia ser homogeneizado como elemento estatístico ou apreendido como segmento de seus arquivos genéticos, exatamente no momento em que seu tratamento é 


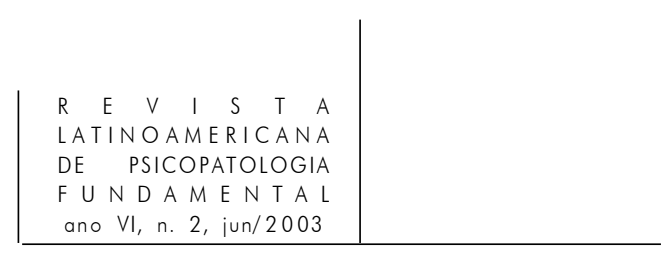

realizado num colóquio singular, onde necessariamente imperam as circunstâncias e o contexto de um drama pessoal e de uma história concreta. Parece-nos que aqui a exigência ética encontra-se inelutavelmente ligada à especificidade da posição médica, e isso para muito além das exigências ordinárias próprias de uma corporação. É exatamente porque um caso clínico individual e concreto não poderia ser reduzido, nas práticas de saúde, à simples aplicação de uma lei de língua científica ou jurídica, que surge no médico uma crise e uma reflexão autenticamente éticas. Obrigado a avaliar os efeitos do que é produzido na sua prática por suas palavras e suas ações num dado contexto - e a nenhum outro idêntico -, o médico confronta-se, quer o saiba ou não, ao alcance de um ato de enunciação. Nesse sentido, os progressos espetaculares dos procedimentos tecnocientíficos da medicina, longe de reduzir o alcance desse ato de avaliação, amplificam dialeticamente aquilo que neles encontra-se em jogo. ${ }^{2}$ É essa a tese do presente artigo.

Desde a medicina hipocrática, a primazia da clínica em medicina, ao privilegiar o caso a caso, acompanhou explicita ou implicitamente numerosas questões éticas. O reflorescimento da ética na atual medicina tecnocientífica poderia ser dialeticamente proveniente do perigo que a clínica corre pelo transporte dos fundamentos da medicina científica do hospital para o laboratório de pesquisa. E isso torna-se ainda mais agudo pelo fato de, na França, essa inversão do centro de gravidade das inovações médicas ter sofrido um processo histórico de reconfiguração das relações entre os médicos, os pesquisadores científicos, o Estado e os industriais da saúde, particularmente a indústria farmacêutica e a das imagens médicas. Essa reconfiguração das práticas e dos saberes de saúde sob a autoridade do laboratório, da indústria e do Estado, constitui tanto um produto histórico, uma invenção coletiva e econômica quanto uma nova tecnologia de discurso ideológico, iniciada desde a época da Liberação, "espelhando-se na América", cujas consequiências estão longe de terem sido avaliadas (Gaudillière, 2002). O recurso à palavra ética poderia se constituir numa maneira de se nomear um ponto de resistência dialética dos clínicos contra essa reconfiguração histórica e ideológica que tenderia a abolir o humano no tratamento do doente.

$\mathrm{O}$ conceito de ética viria oportunamente designar uma aporia, um impasse na formalização dos saberes da saúde, no momento em que esses saberes científicos encontram-se confrontados a uma aplicação nas práticas médicas. Devendo levar em consideração a demanda do doente numa escuta singular e concreta, a prática médica não mais encontra no saber científico o manual de

2. No sentido em que Martin Heidegger cita Hölderlin; “Ali onde cresce o perigo, também nasce aquilo que salva." 


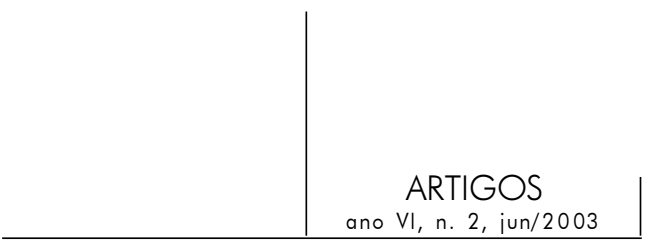

instrução capaz de guiá-la. Lembremos, de passagem, a declaração de Lacan em sua conferência de 1966 sobre o lugar da psicanálise em medicina:

O médico é solicitado na função de cientista fisiologista, mas ele sofre ainda outros apelos: o mundo científico derrama em suas mãos a infinidade daquilo que pode produzir, como novos agentes terapêuticos, químicos ou biológicos, que ele coloca à disposição do público, e ele pede ao médico, como a um agente de distribuição, que os coloque à prova. Onde está o limite que estabelece até onde o médico deve e ao que ele deve responder? A qualquer coisa que se chame a demanda. [...] É no registro do modo de resposta à demanda do doente que se encontra a chance de sobrevivência da posição propriamente médica. (p. 39-40, grifos nossos)

Postulemos, por enquanto, que a prática não é simples aplicação de um saber científico, mas que ela produz necessariamente uma referência à ética e mesmo à política, ou ainda à psicanálise enquanto significantes nomeando pontos de impasse da medicina tecnocientífica. A menos que a prática se degrade em técnica, ${ }^{3}$ essas referências à ética, à política, e mesmo à psicanálise, parecemnos constituir o outro do discurso tecnocientífico, seu negativo, o resto heterológico ${ }^{4}$ que as tecnociências necessariamente produzem realizando sua legítima progressão no seio da medicina.

Os colóquios sobre "Pediatria e psicanálise"5 são um testemunho evidente de que foi sobre a aresta viva da ética que os médicos e os psicanalistas puderam se encontrar e dialogar. Esse cuidado ético faz com que a relação doente-médico seja reconhecida e abordada para bem além dos saberes sobre a doença e dos protocolos médicos que estes exigem. Em outros termos, esse cuidado ético consiste em admitir que embora as ciências médicas tenham progredido necessária e legitimamente graças ao estudo das doenças, e mais recentemente dos fatores de risco, suas práticas não poderiam se reduzir a uma pura e simples aplicação desse saber tecnocientífico. É exatamente porque as práticas de saúde de modo

3. Cf. Gadamer, para quem o esquecimento moderno do sentido autêntico das práticas degradadas em técnicas provém do desconhecimento da natureza essencialmente dialógica da fala e da linguagem. Ele escreve: "O progresso da técnica encontra uma humanidade que ela pega desprevenida" (1993, p. 35).

4. O termo "heterológico" aproxima-se aqui do "real" lacaniano. Como lembram Elizabeth Roudinesco e Michel Plon (2000), Lacan toma de Georges Bataille seu conceito de uma "heterologia", "ciência do irrecuperável", da "parte maldita", para forjar seu conceito de "real" (p. 898).

5. Esses colóquios geraram a publicação de quatro obras coletivas sob a direção de Danièle Brun. A quarta dessas obras intitula-se Techniques médicales et fantasmes. Au nom d'un projet d'enfant parfait" [Técnicas médicas e fantasmas. Em nome de um projeto de uma criança perfeita], Paris: Études freudiennes, 2001. 


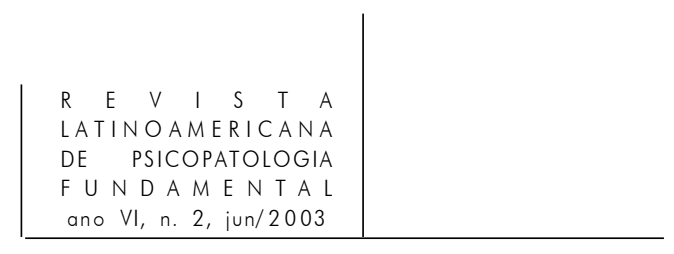

algum resumem-se a uma técnica, que elas devem levar em conta os sofrimentos humanos, irredutíveis às doenças, e que elas convocam o julgamento e a decisão do médico ou da equipe médica. Esses conceitos de "julgamento" e de "decisão" constituem os operadores, os mediadores, entre o mundo do saber e o da ética. Nesse sentido, as práticas médicas e as práticas psicanalíticas podem ser consideradas convergentes em termos de uma casuística, uma lógica do caso a caso, singular, irredutível às leis do saber científico ou jurídico. Não existe "silogismo prático" (Cf. Lagrée, 2002) permitindo dizer, em psicanálise ou em medicina, que a tal problema concreto e individual corresponderia necessariamente tal ou tal solução. Não é porque são utilizados protocolos terapêuticos padronizados que podem ser dispensados o julgamento e a decisão impostos ao médico pela situação concreta do colóquio médico e a singularidade do caso do qual ele deve cuidar. Sem isso, a instrumentalização do corpo humano, que por vezes mostra-se necessária à lógica tecnocientífica e que se encontra enquadrada pelos imperativos morais culturais, aboliria no próprio ato do diagnóstico e do cuidado, a dimensão humana tanto do paciente quanto do médico. Se cuidar, como diz Canguilhem, é "fazer uma experiência", esta deve ser necessariamente de natureza diferente da experiência científica que a segue ou precede. A experiência do cuidado inevitavelmente prescreve uma avaliação, diferente da avaliação própria ao procedimento científico. Ou seja, uma avaliação feita de julgamentos e decisões sobre os quais a psicanálise mostra serem fabricados tanto em e pela racionalidade quanto pela presença de processos inconscientes determinados pelo encontro e seus efeitos. A mínima deve ser consensualmente considerado que o médico e a equipe de cuidadores terão sempre que avaliar os meios a serem utilizados para tal caso concreto e tal situação sempre particular. É aqui que a palavra "terapia" encontra sua significação etimológica de "tomar cuidado", de "servir" na "solicitude" e na "delicadeza"

Tomemos o caso das pesquisas genéticas freqüentemente mencionadas nos trabalhos dedicados às questões éticas. O procedimento e os resultados dessas pesquisas genéticas mostram que elas dizem mais do que simplesmente aquilo pelo qual foram realizadas: em suma, que a verdade que elas proclamam excede a exatidão que elas anunciam. Assim, a constituição da carta genética de uma família por vezes revela falsos parentescos, exuma segredos de família, produz uma "culpabilidade dos sobreviventes" naqueles que não são portadores do gene patológico, assume o peso de uma ameaça de morte ou de sofrimento para outros, ou ainda atualiza desejos inconscientes de morte ou de incesto, particularmente gritantes no caso do diagnóstico pré-natal. Como diz Arnold Munnich, diante da culpabilidade dos casais que o consultam, o geneticista é convocado a exercer uma onipotência, a de ter que ler " "no livro aberto dos genes', da mesma forma que se atribui ao psicanalista o poder de ler nos pensamentos" (Munnich, 2001, 


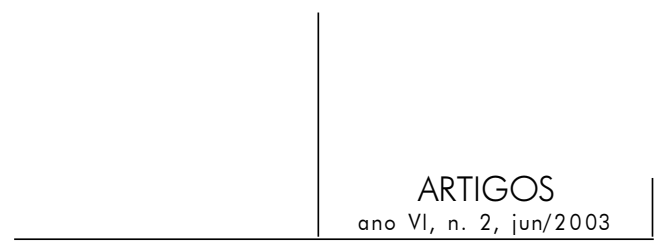

p. 24). Assim, o geneticista torna-se o mensageiro do destino, ou seja, do superego. Ele não se limita mais a dar uma informação probabilística, mas realiza, ao menos para o psiquismo, um prognóstico que assume o valor de danação, maldição ou predestinação, por vezes no horizonte dos atos de fala performativos que realizam aquilo que dizem. E sem dúvida é por ser um especialista altamente competente e reconhecido em sua ciência que Arnold Munnich pode acolher em sua prática esse resto heterológico à sua técnica quando escreve:

Minhas mais didáticas explicações freqüentemente me dão a sensação de ensurdecer meus interlocutores, como se eu tivesse sido deixado de lado... Assim, como nossos pacientes exigem de nós mais do que explicações racionais, porque a busca de um sentido para esses golpes do destino é onipresente, senti muito cedo a necessidade de associar psicanalistas a nossas consultas de genética. Para ajudar-nos a compreender, para tentar responder com uma dupla escuta às múltiplas vozes que se misturam nos discursos de nossos pacientes... (Ibid.)

Aqui, a ética não se reduz mais a um suplemento de alma acrescentado às práticas da saúde e a sua molecularização científica. O médico reconhece que na própria realização do ser vivo, o vivente humano se especifica pela fala. Nesse reconhecimento de uma pertença recíproca do ser e da fala, o médico se reúne ao psicanalista e cria lugares de cuidado permitindo que, pela fala dirigida a um Outro, não se sofra em vão.

Vamos concluir sobre esse ponto. Por meio de uma tomada de partido metodológica, distinguimos com razão o sofrimento em nome do qual todo paciente vem se consultar enquanto configuração de signos clínicos ou biológicos, evocadores de doenças objetiváveis (Disease em inglês), de seu valor de discurso ou de prova intersubjetiva (Illness) e finalmente de sua inscrição simbólica em uma língua, uma cultura, uma economia, e até mesmo em uma ideologia e uma política de saúde (Sickness). Acontece que esse posicionamento metodológico, por mais operacional e legítimo que seja na construção de nossos objetos de saber, encontra-se subvertido nas práticas de saúde pela polissemia e pela polifonia dos discursos, que só se tornam reduzidos devido às escolhas realizadas pelos ouvidos que os recebem. ${ }^{6}$

Nas práticas de saúde, a ética é deduzida do reconhecimento de que, por meio das nossas tomadas de partido metodológicas, realizamos necessariamente interpretações que exigem, no diálogo do diagnóstico e do cuidado, inovações que as transcendem. A tradição clínica em medicina admitia isso mais ou menos explicitamente. A ideologia tecnocientífica atual finge por vezes ignorá-lo. Por exemplo, entre o saber do médico sobre a doença do corpo e a verdade ontológica

6. G. Bachelard escrevia: "Então o ouvido é ativo, pois prestar ouvidos é se prestar a dar." 


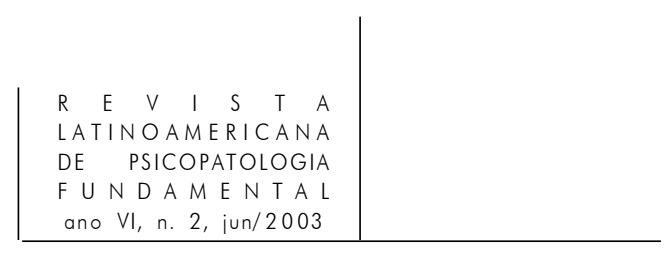

do doente, há toda a distância que separa em alemão a palavra "Körper" (a matéria corporal) da palavra "Leib" (a carne) (Gadamer, 1993). Quanto ao psicanalista, que devido a seu método só se interessa pela carne, ele não poderia esquecer que o corpo é também essa matéria impossível de ser abordada sem os meios dos quais ele se priva para garantir aqueles dos quais ele se dota. Talvez seja nesse ponto que a ética exige tanto um tratamento plural do doente quanto uma solicitude singular na assunção do diálogo. Desse modo, devemos ainda uma vez nos curvar diante das afirmações de Canguilhem que situam o

... poder e [os] limites da racionalidade em medicina: a racionalidade médica realiza-se no reconhecimento de seu limite, entendido não como o fracasso de uma ambição que deu tantas provas de sua legitimidade, mas como a obrigação de mudar de registro. Finalmente, é preciso admitir que não pode haver homogeneidade e uniformidade de atenção e de atitude no que concerne a doença e o doente, e que o tratamento de um doente não pertence à mesma responsabilidade que a racionalidade contra a doença. (Canguilhem, 1978, 1989, p. 408, grifos nossos)

\section{A polifonia dos discursos no campo da saúde}

Quando Arnold Munnich evoca essa múltiplas vias que se fazem escutar no colóquio médico, ele se encontra, sem dizê-lo, junto a muitos trabalhos de filosofia da linguagem, de pragmática dos discursos e de psicanálise que - cada um de seu modo - arrebentam com a ilusão de uma unidade do sujeito falante confundido com o locutor. A "confusão das línguas" no sentido de Ferenczi (1933, cf. também Stein, 1988), é freqüentadora habitual do colóquio médico e, para além mesmo das consultas e do tratamento, do conjunto dos discursos de saúde, até e inclusive os discursos de prevenção acoplados às pesquisas de higiene e epidemiologia. $\mathrm{O}$ efeito desses discursos provêm tanto das informações médicas e probabilistas que eles fornecem, quanto dos equívocos semânticos e fônicos sobre os quais inevitavelmente se dão, sabendo-o ou não. Voltaremos a isso. Por enquanto, vamos nos contentar em reafirmar mais uma vez que no campo da saúde o dito sempre excede o dizer.

Danièle Brun (1989) abriu uma via paradigmática em A criança dada como $m o r t a$, a partir de sua experiência de psicoterapeuta e psicanalista num serviço hospitalar para crianças sofrendo de cânceres. Ela constatou um paradoxo que diz respeito, em nosso sentido, aos caráteres polifônicos e dialógicos (Bakhtine) dos discursos no campo da saúde: o anúncio aos pais da "cura" médica do câncer de seus filhos não produz a satisfação que se esperaria de seus desejos manifestos. $\mathrm{O}$ efeito de anúncio desse acontecimento médico não produz o acontecimento 


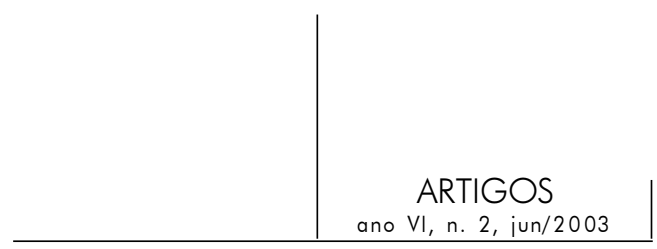

psíquico esperado, pois ele exige um trabalho suplementar, o de ter que fazer o luto de um luto, de ter que elaborar as representações infanticidas que a idéia obsedante da morte do filho encobria. Nesse sentido, a comunicação de um dado médico (a cura do câncer da criança) assume o valor de interpretação selvagem das representações infanticidas dos pais. Assim, a comunicação de informação revela no diálogo, e no campo da saúde talvez mais do que em qualquer outro lugar - devido ao núcleo hipocondríaco constitutivo - a relação desnaturada do sujeito humano com seu corpo.

O fato de, no campo da saúde, o dizer exceder o dito, da informação poder trazer uma revelação, abre inevitavelmente o reino dos valores e, portanto, da ética. $\mathrm{O}$ médico encontra-se inelutavelmente, quer queira ou não, quer saiba ou não, obrigado a ter que avaliar o alcance de seu ato de enunciação, ou seja, de seus efeitos sobre o outro. Tomemos dois exemplos.

O primeiro constitui um caso paradigmático da reflexão ética em medicina produzida pela conflitualidade das vozes que se fazem escutar num discurso médico. É o momento crítico em que o colóquio médico exige-lhes um discernimento ético que vai muito além das prescrições legislativas e ordinais de ter que dizer a verdade ao doente. Mas, por enquanto, constatemos no caso que iremos relatar quanto à crise moral que toma conta do médico é resolvida na pura tradição clínica da medicina, mesmo com o risco de desafiar, como Antígona, as leis da Cidade por uma necessidade superior. Esse caso é relatado por um médico clínico geral, François Baumann. ${ }^{7}$

Trata-se de um paciente tratado devido a um câncer brônquico, que o fará falecer durante a hospitalização. Sua esposa é informada desse diagnóstico e irá passar por um difícil luto pelo marido. Após um ano, provavelmente após o trabalho de luto, ela considera a possibilidade de refazer sua vida com um namorado. Seu clínico geral fica sabendo, incidentalmente, por um dos médicos que cuidava do marido, que ele não faleceu devido ao câncer anunciado, mas por causa de uma afecção oportunista ligada à Aids de que sofria. O hospital tinha informado o médico do marido da causa real do falecimento, que por sua vez transmitiu a informação ao clínico geral da esposa. Ora, esta ignora a causa real do falecimento de seu marido, mesmo podendo ter sido contaminada e correndo o risco de, por sua vez, contaminar o namorado. Como nota Jacqueline Lagrée, de quem tomamos a análise deste caso, os médicos encontram-se diante de um conflito de valores, conflito entre

... o respeito de um segredo médico inviolável e perene [que] entra em contradição com um outro dever, que pode ser julgado prioritário, de prestar assistência a uma pessoa potencialmente em perigo. O problema se complica ainda mais, pois

7. Caso citado por J. Lagrée, 2002. 


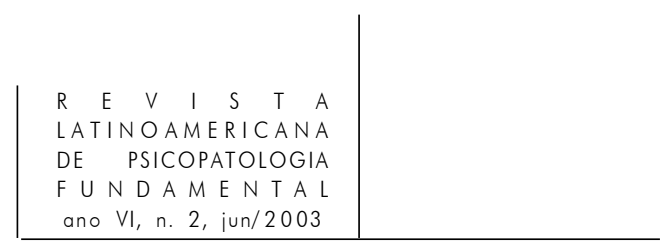

esse doente nunca havia interrogado detalhadamente os médicos sobre sua doença. (Lagrée, 2000, p. 99-100)

Os médicos decidiram incentivar a esposa e seu namorado, de forma delicada mas firme, a realizar um check-up incluindo um teste de HIV, indicando que se tratava agora de um procedimento habitual quando as pessoas decidiam casar. Como os testes deram resultados negativos, os médicos e os pacientes se tranqüilizaram, e o segredo médico foi preservado. Sem ter que entrar com mais precisão na análise deste caso, notemos simplesmente que transmitir aqui uma informação médica, faria revelações em diversos níveis de partição do sentido e sem dúvida produziria uma crise subjetiva e intersubjetiva nos diferentes protagonistas deste drama.

Assim, é preciso privilegiar o direito de saber ou o direito do saber, ${ }^{8}$ para retomar a distinção que Jacqueline Lagrée emprega a respeito do "direito à saúde" e do "direito da saúde". Considerando as coisas de nosso ponto de vista, o direito de saber constitui um direito do indivíduo, cidadão e sujeito de direito capaz de recusar de se deixar despossuir de uma informação que o concerne numa relação que subscreve. Mas isso também equivale, enquanto sujeito, a reconhecer-lhe um direito de recusar uma informação traumatizante com respeito à qual ele não subscreveu previamente uma adesão para saber. Ora, somente o caráter dialógico do colóquio médico revela tanto a demanda quanto o desejo de saber do sujeito. Mas ainda é necessário precisar: o que entendemos por "saber" ou por “informação"? Não há dúvidas que o saber esperado do doente não se inscreve no mesmo alcance que o oferecimento do saber do médico. Retomando uma expressão de Barthes, a língua assume um caráter fascista quando ela obriga a dizer. Ora, o direito do saber consagra a primazia do saber sobre o sujeito, sujeito do direito ou sujeito do inconsciente. O direito do saber, é a obrigação de dizer em nome do saber, seja esse saber científico ou jurídico. Em nossa cultura americano-centrípeta, o direito do saber tende a substituir o direito ao saber. No entanto, como mostra o exemplo precedente, os médicos não poderiam - a menos que se demitissem de sua posição propriamente terapêutica - renunciar, no colóquio com seus pacientes, a fazer prevalecer o direito a saber sobre o direito do saber; de outro modo, eles mesmos se tornariam iatrogênicos e teriam que confiar a outros especialistas o tratamento dos efeitos indesejáveis que produzem. Será que isso vai acontecer, num dia próximo? Lançar mão do "psi” vai acabar por se inscrever nesse tipo de molecularização do tratamento do doente? Mas se isso ocorrer, será em detrimento da clínica, caso esse recurso ao psi não for acompanhado de uma reflexão ética plural da equipe de cuidadores. Sem isso,

8. Como se diria, o direito de ser informado, que se distingue da obrigação de se informar. 


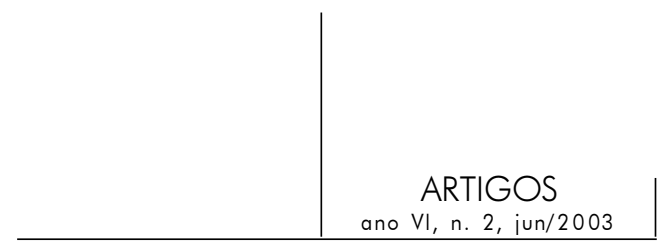

esse recurso ao psi poderia produzir exatamente o contrário do que se espera; ou seja, longe de devolver à doença e ao tratamento sua dimensão ontológica e ética, ele tenderia a eximir os outros parceiros do tratamento do cuidado de avaliar os efeitos que eles produzem com seus dizeres no trato com o doente, descarregando sua responsabilidade simbólica em outro "técnico".

Retomando o exemplo citado, estamos totalmente de acordo com Jacqueline Lagrée para reabilitar aqui o velho conceito de "casuística" e ressaltamos, de nosso lado, sua afinidade com uma ética propriamente médica que se mostra inseparável do primado da clínica sobre o direito e a ciência. Dizer a verdade, aqui como em outras situações, não significa transmitir selvagemente uma informação exata ou provável com relação às quais estaríamos quites de uma vez por todas, mas é também avaliar os efeitos que seu dizer produz numa dada situação para sujeitos necessariamente singulares. Sem o quê o médico estaria se destituindo de sua função terapêutica e da dimensão ética de seu ato.

Tomaremos brevemente um segundo exemplo da prática de um dentre nós. Trata-se de uma paciente de 70 anos e curada, há mais de 25 anos, de uma doença de Hodgkin. A doença começou com um gânglio cervical diagnosticado e tratado por seu clínico geral como uma tuberculose. Por ocasião de uma visita à sua vizinha, a paciente encontra o médico desta última e se faz examinar aconselhada pela vizinha. Exames complementares mostram-se necessários e revelam alguns dias mais tarde a doença de Hodgkin. A sra I. é então encaminhada ao professor P., que lhe diz que é preciso agir rápido. É preciso que ela seja hospitalizada o mais rapidamente possível. Isso acontece perto do período das festas de Natal, e a sra. I. exprime o desejo de passar o Natal com seus dois filhos, que têm oito e dez anos. Para convencê-la da urgência da hospitalização e do tratamento, o prof. P. lhe diz "minha filha", e ela ri quando evoca essa expressão, "a escolha é sua: um Natal sem teus filhos ou um Natal com e os outros sem”. De fato, ela consegue uma licença para o Natal. Outras palavras proféticas do prof. P: ele lhe diz que, se optar pelo tratamento, ela irá sofrer e que será muito duro: radio e quimioterapia; mas que se ela fizer tudo o que ele lhe diz, então irá se curar, ela irá se curar em cinco anos. A sra. I. confirma que foi tudo muito duro e, principalmente, que as datas estavam exatas. Conserva sempre essas datas na cabeça e foi exatamente após cinco anos, contados dia a dia após o início do tratamento, que o prof. P. The anuncia que ela estava curada. Quando ela o agradeceu, ele lhe disse que ela só devia sua cura a si própria.

Durante a consulta, as palavras do prof. P. não se limitam a transmitir à paciente uma informação probabilística sobre o prognóstico e as modalidades

9. "Estudo dos casos de consciência, ou seja, dos problemas de detalhe que resultam da aplicação das regras éticas a cada circunstância particular" (A. Lalande, 1993). 


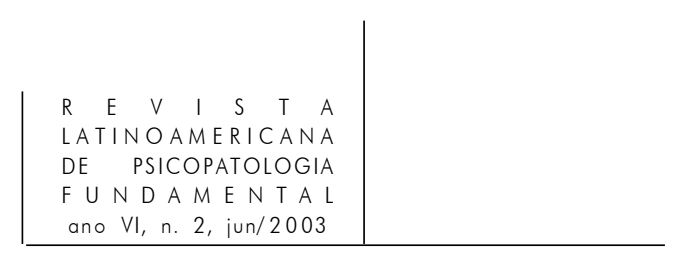

pelas quais ela deverá passar para ser tratada com sucesso. Os fragmentos de discurso que a paciente relata, o tom do professor tal como ela o descreve, os efeitos que eles produzem sobre ela, ou ao menos em sua memória, mostram como é ainda vívida a lembrança de uma cena que não é apenas acontecencial, mas também constitutiva de traços psíquicos aos quais vêm se acrescentar outras lembranças de sua infância. A tática adotada pelo prof. P. leva a sra. I. a se submeter a sua estratégia terapêutica: ela toma os caminhos da infantilização da paciente e de uma ameaça de morte cujo caráter absoluto assume um tom profético para ser mais eficaz. Em suas lembranças, a paciente relata uma cena que mostra claramente o caráter polissêmico da palavra "tratamento". Tratar um paciente não é apenas aplicar um protocolo de cuidados padronizados por estudos científicos prévios, mas é também tratá-lo de um certo modo, no sentido de lidar com ele de uma maneira, ou seja, uma maneira de se ocupar dele, de se comportar com, de se conduzir com ele. Etimologicamente, a palavra "tratamento" deriva, no século XIII, da palavra "tratação", no sentido de "deliberação", "negociação", e "tratar" vem do latim "tractare", supino de "trahere", "ordenhar" (Rey, 1992). Podemos assim constatar que a língua que o professor usa para informar sua paciente e convencê-la, constitui um meio de "ordenhar" as coisas de tal modo que implique tanto num discernimento ético diante do problema moral que ela lhe coloca quanto numa implicação intersubjetiva que inclui no diálogo a problemática singular de cada um dos protagonistas.

É claro que no relato que nos fez, as lembranças da paciente restauram menos o acontecimento material do encontro do que o sentido e os efeitos psíquicos que esse encontro produziu e o alcance que ele assumiu no discurso que nos é dirigido. A história pertence propriamente à paciente: aqui iremos apenas mencionar aquilo que, após o discurso que ela nos dirige, vem esclarecer o sentido revelado pela lembrança das palavras do professor: dívida e culpabilidade. A dívida, como sabemos, tem a ver com a falta, e "Schuld", em alemão, é tanto "dívida" quanto "falta". No discurso que nos dirige, a sra. I revela de que maneira ela conserva as lembranças das palavras do professor para manter-se na falta. Já dissemos várias vezes, mas vamos repetir: a doença e as palavras que a anunciam e que prescrevem o tratamento podem constituir "o representante de todas as fantasias inconscientes que aguardavam a primeira ocasião de se manifestar" (Freud, 1916/17, p. 369). Mas essas ocasiões são inseparáveis da realidade discursiva do colóquio médico, dos equívocos da língua, da função poética da linguagem e dos efeitos do ato de fala nas condições em que ele se realiza e na conjuntura em que ele intervém.

Para concluir quanto a esse ponto, digamos que o "caso", no campo da saúde, não é somente o paciente, e ainda menos sua porção exata de elementos estatísticos de uma "coorte", mas muito mais uma situação concreta e única de 


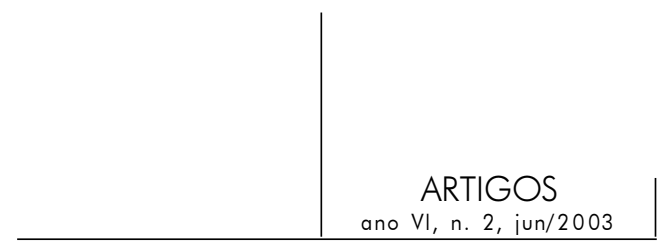

interlocução que inclui, de maneira dialógica, os diversos protagonistas. No interior dessa situação, o interlocutor participa do sentido do enunciado que o outro lhe dirige, e muitas vezes, através dele, a um "sobredestinatário" (Bakhtine), a um grande Outro, como diriam os psicanalistas. A significação de um enunciado, é seu uso que depende estreitamente do contexto de enunciação e cujos desdobramentos simbólicos abertos em sua ação o psicanalista revela. Assim, a verdade transmitida no colóquio de diagnóstico e de cuidado só poderia ser avaliada pelos seus efeitos. Ela toma como seu horizonte a palavra "justa", a palavra que convém à situação, e não somente ao caso ou ao médico. Portanto, ela implica numa clínica autenticamente ética, capaz de solicitar a escuta do médico, sua capacidade de escutar as necessidades e os desejos do paciente, um discernimento moral e uma reflexão crítica que não são fornecidos nem pelas leis da ciência, nem pelas do direito. Dessa forma, o médico, que aceita não dissociar o componente cognitivo de seu ato de fala de seu componente pragmático, que se recusa a tratar seu paciente como seria tratada uma informação num computador, está mais construindo uma ética em ato do que se referindo a uma ética já constituída. Dessa forma, o médico encontra-se diante da necessidade de ter sempre que auscultar a clínica singular da situação no interior da qual ele age. É nesse sentido que sustentamos aqui a tese segundo a qual as preocupações éticas nas práticas de saúde constituiriam atualmente um novo desvio para reatar com a primazia de uma clínica relegada a pano de fundo do laboratório de pesquisa ou de enquetes epidemiológicas.

Mas essa preocupação de avaliar os efeitos dos discursos de saúde sobre o doente do qual o médico cuida parece-nos inseparável dos fatos de linguagem e de fala: uma mensagem é sempre escutada ali onde é esperada. A língua é equívoca. Nenhum enunciado é separável de sua enunciação e um discurso se inscreve necessariamente nas pautas de várias partituras.

Gostaríamos de concluir evocando brevemente como a própria retórica dos discursos de saúde e de prevenção, em sua forma atual, toca esses equívocos, com sua polissemia e sua polifonia, interpretando selvagemente, pode-se dizer, a hipocondria primordial do sujeito humano, tocando especialmente a promessa de cura.

\section{Para concluir sobre a cura e seus equívocos}

Notemos desde já a polissemia da maior parte dos termos que se referem, mais particularmente nos discursos de prevenção, à saúde e à cura. Essa polissemia desempenha um importante papel não somente nas ideologias médicas, nas propagandas de salvação pública, mas também na maneira pela qual os pacientes recebem a informação no colóquio médico e esperam deste uma cura. 


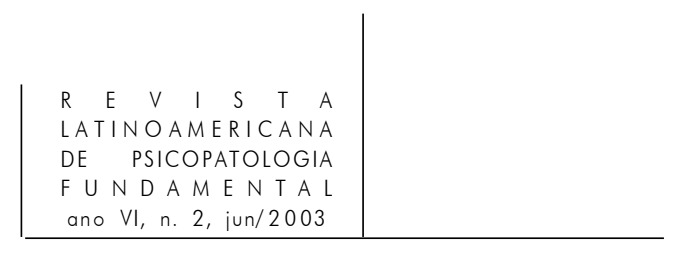

Veremos até que ponto essa expectativa tende a conferir à cura a significação de um ressurreição (Cf. Forthomme, 2002).

Vamos dar alguns exemplos. O termo saúde não designa apenas, no uso que dele fazemos, a ausência de doenças ou o "silêncio dos órgãos", caro a Leriche. Esse termo, em vários lugares das retóricas de saúde e dos discursos de propaganda de prevenção, remete tanto à "salvação religiosa", ${ }^{10}$ metafísica, mística, quanto à "salvação pública" (Foucault, 1974-75 e Skrabanek, 1994) do Estado capaz de controlar normativamente os indivíduos e as populações, e finalmente a um elemento das tecnologias discursivas do mercado econômico e comercial sob os auspícios midiáticos de uma "forma" a ser buscada ou encontrada. Pode-se dizer da saúde aquilo que Santo Agostinho dizia sobre o tempo: "Se ninguém me coloca essa questão, penso saber o que ela é, mas se me pedem para defini-la, encontro-me diante de uma grande dificuldade". Essa dificuldade é ainda maior pelo fato de, no século XX, a saúde não ser mais apreendida apenas como uma ausência de doença, mas antes como uma modalidade do pathos próximo da felicidade.

Em 1946, nos estatutos da OMS, a saúde encontra-se definida não somente como a "ausência de doença ou enfermidade", mas ainda como "um estado de bem-estar físico, mental e social". Como nota Skrabanek, tal definição da saúde aproxima-se de uma "sensação que o comum dos mortais consegue experimentar brevemente durante o orgasmo ou sob a influência de drogas" (1994, p. 45). A Organização Mundial da Saúde estaria assim promovida ao papel de Grande Hipnotizador das Massas. Essa extensão do conceito de saúde aos saudáveis estende consideravelmente o poder da medicina e dos médicos, encarregados não somente de tratar dos indivíduos, mas também das populações. Baseando-se em enquetes epidemiológicas que exumam os fatores de risco e de morbidade, quase sempre ligados a prazeres inúteis para a economia (álcool, tabaco e sexo), ${ }^{11}$ as retóricas de prevenção promovem um dever de saúde que se assimila, por múltiplas vias, aos tabus alimentares e aos regimes "ortobiótipos" (Ibid.).

10. Cf. Os sinais de cura e a figura do Cristo médico na obra de Forthomme, 2002.

11. Ou que incomodam. A questão de saber se convém ministrar Ritalina às crianças hiperativas estabelece de facto uma norma de atividade. É nesse sentido que progridem as diferentes versões do DMS que substituem o sofrimento do sujeito por critérios capazes de diagnosticar "desordens" ("Disorders"), "distúrbios" do comportamento. Esse instrumento é considerado "científico", "ateórico", mas ele se baseia em grande parte num método de expertise grandemente influenciado pela cultura americana, sua opinião e suas ideologias (cf. E. Zarifian, 1994). Assim, esse tipo de instrumento "objetivo" congregado com interesses farmacêuticos e com uma ideologia neurobiológica (ou melhor, neurozoologia) transformará o paciente esquizofrênico no meio encontrado por uma molécula (antipsicótica) para produzir uma outra molécula. 


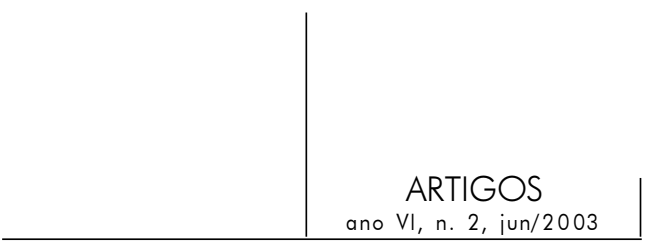

Sejamos mais precisos. Não se trata aqui de contestar a validade das informações probabilísticas que as campanhas de prevenção oferecem ao consumo midiático das populações. Tampouco se trata de realizar pesquisas históricas ou antropológicas capazes de mostrar a existência de uma solidariedade entre a higiene sanitária, ${ }^{12}$ os dispositivos de Salvação Pública, ${ }^{13}$ as tecnologias discursivas de normalização social e política pela perícia, ${ }^{14}$ as ideologias totalitárias, ${ }^{15}$ a expropriação médica da saúde (Illich, 1975) e a estrutura das retóricas de prevenção. Outros autores já realizaram muito bem tal tarefa. Nosso propósito aqui visa antes mostrar como a própria polissemia dos termos atinentes à saúde, aos quais esses discursos se referem, autoriza-os a se inscreverem em várias pautas de uma partitura, e age, principalmente para alguns sujeitos, sobre o registro ético da culpabilidade e da dívida. Essa retórica da prevenção não somente realiza a primazia de um direito da saúde sobre o direito à saúde, mas esses discursos, ainda, oferecem aos protagonistas do colóquio terapêutico os envelopes formais de seus sintomas na construção dos "romances da doença", (Del Volgo, Gori, Poinso, 1994; Del Volgo, 1997), capazes de dar um sentido ao que acontece de doloroso na vida.

Desde que a epidemiologia deixou os limites do campo das patologias infecciosas para participar ativamente da gestão dos estilos de vida, de um "bioestilismo" (Skrabaneck, 1994), abre-se o reino do controle moral e normativo. Aí ela toma a palavra, tal Cassandra, em nome do destino, oráculo que assume o lugar das ameaças superegóicas: "Se você não se comportar bem, como se deve, será punido"; "Você se tornará um mau patriota";16 "um mau cidadão", "um mau consumidor", ${ }^{17}$ "maus pais de família", ${ }^{18}$ e finalmente "Você vai ficar doente e acabar morrendo" e "Você não merece ser cuidado"19 ...

12. O Instituto de Higiene Sanitária foi criado em 1942, sob o Governo de Vichy.

13. O primeiro serviço governamental de Saúde Pública foi criado em 1789, sob a Revolução, e foi confiado ao Dr. Guillotin.

14. M. Foucault, 1974-75, sobre a perícia médica: "O criminoso já se assemelhava a seu ato antes de tê-lo cometido".

15. Os sovietes e os nazistas fizeram da saúde pública uma prioridade que permitia iniciativas higienistas ou segregações políticas.

16. Para Joseph Goebbels, tomar café era um ato antipatriótico.

17. Sobre a proibição do álcool nos Estados Unidos, Henri Ford dizia: "Ela é economicamente boa. Ora, nós sabemos que o que é economicamente bom, também é moralmente bom".

18. O efeito perverso das campanhas antitabaco levou certos tribunais americanos a considerar que pais fumantes eram inaptos para a guarda de seus filhos. Alguns advogados incentivaram os filhos a dar queixa contra os pais pelo prejuízo sofrido enquanto fumantes passivos.

19. P. Skrabanek, 1994, relata casos de médicos que se recusaram a tratar de fumantes por afecções sem relação com o tabaco. 


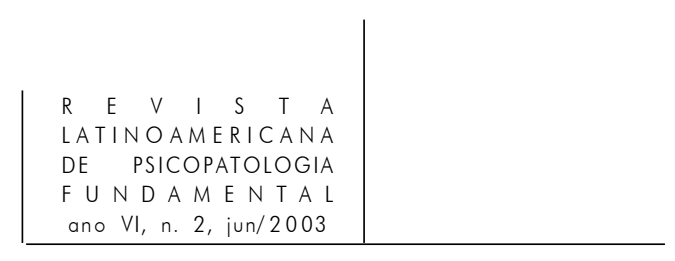

Em suma, a promoção do culto da saúde e da forma, as propagandas que nela se inspiram, assim como os comércios e serviços que dela se nutrem, por vezes têm suas fontes, embora nem sempre, nas grotescas figuras do superego, preconizando sanção e vigilância, combatendo os prazeres inúteis, em nome de um conformismo que poderá também constituir o incitador-ao-gozo do erotismo. Nessa paixão conformista (Gori, 2002), cumpre-se o ódio, o ódio do outro, do estrangeiro, do diferente, do singular. Ódio legítimo, pois ele permite conciliar o ódio do outro com a solidariedade minimalista a uma certa comunidade, não sem contribuir com sua cota ao patrimônio dos interesses econômico-midiáticocomerciais dominantes e ao rastreamento ético-político das populações pelo Estado.

Em obras (Skrabanek, 1994; Skrabanek e McCormick, 1989) revigorantes, originais e muito bem documentadas, Skrabanek, professor de medicina e membro da equipe editorial do Lancet, denunciou com brilho o "totalitarismo rastejante" do "culto de uma supersaúde", o perigo de uma normalização coletiva dos comportamentos erigida em política de Estado. Essa ideologia médica, essencialmente anglo-americana, é dominante nas democracias ocidentais desde 1970 e não pára de estender aos saudáveis a magnificência de sua gestão no menor detalhe da vida cotidiana. Essas obras constituem uma violenta crítica do "higienismo contemporâneo" que explora desavergonhadamente a hipocondria dos indivíduos através de uma vigilância sempre crescente dos estilos de vida capazes de conciliar um puritanismo moral e a homogeneização conformista das condutas com dispositivos político-econômicos sempre mais invasivos e por vezes muito nocivos.

Finalmente, é preciso indicar com ainda mais precisão que esses fantasmas semânticos das morais e da higiene assombram não somente as retóricas dos discursos e saúde, mas também os envelopes formais do colóquio terapêutico. Eles oferecem, tanto aos pacientes quanto aos médicos, ideologias prontas a racionalizar seus atos, assim como formas lingüísticas mais ou menos vazias de significados, significantes análogos aos restos diurnos no trabalho do sonho e capazes aqui de constituir hieróglifos de seu sofrimento.

E quanto à cura? Seu conceito mostra-se inseparável do de doença e de extensão polissêmica que essa noção adquiriu na história das práticas de saúde, como acabamos de tentar evocar.

Canguilhem lembra que etimologicamente: "curar é proteger, defender, munir, quase militarmente, contra uma agressão ou uma sedição. A imagem do organismo aqui presente é a de uma cidade ameaçada por um inimigo exterior ou interior. Curar é guardar, resguardar" (2002, p. 73). Essa concepção da cura como ofensiva-defensiva contra uma agressão ou uma desordem corporal, toma portanto como metáfora invasões ou transtornos sociais que se apoderam de uma 


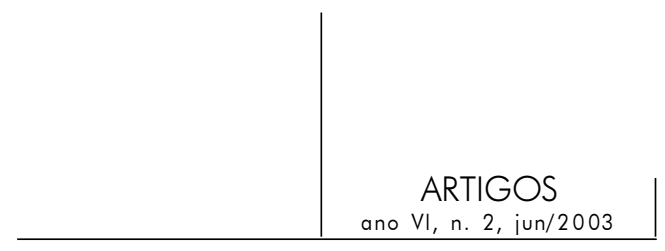

Cidade. Essa metáfora é acompanhada da crença segundo a qual um retorno à ordem anterior seria possível: "Nesse sentido, cura implica na reversibilidade dos fenômenos cuja sucessão constitui a doença..." (p. 75). Essa crença encontrase solidamente implantada no discurso comum da opinião ou nas afirmações do doente, que considera a cura como um reencontro com sua saúde anterior, assim promovida a estatuto de bem perdido ou deteriorado. Por intermédio de processos de cristalização totalmente comparáveis aos processos amorosos, essa saúde anterior é muitas vezes bastante idealizada, sendo que o sujeito não teria ainda plena consciência de todo seu valor no momento em que dela desfrutava.

A modificação do conceito de doença no decorrer do século XX, como acima evocada, leva a revisar o conceito de cura sob o ângulo não de uma restituição ad integrum desse bem, mas sim da recuperação da capacidade de dele desfrutar. Estar bem consiste então em se comportar bem nas situações que devem ser enfrentadas, por meio dos recursos disponíveis, sem dúvida físicos, mas também psíquicos e sociais. Esse deslocamento do centro de gravidade dos conceitos de cura prepara, de certa maneira, o reconhecimento de que a cura na realidade psíquica não se inscreve necessariamente no mesmo lugar e segundo a mesma sintaxe que a cura atestada do ponto de vista médico. Aqui, surge mais uma vez a sombra da ética, dependendo se o médico irá querer ou não levar em consideração esse fato psicanaliticamente bem estabelecido (Brun, 1989). Será que o médico terá cumprido a contento sua missão quando, munido de seus protocolos terapêuticos, legítimos e preciosos, tiver devolvido ao paciente suas capacidades físicas? Isso significaria esquecer que: "as doenças do homem não são somente limitações de seu poder físico, mas dramas de sua história. A vida humana é uma existência, um ser-aí para um devir que não é pré-ordenado, no temor de seu fim" (Ibid., p. 89). Pensamos que é exatamente nesse ponto que o psicanalista tenha algo a dizer. Não que ele seja convidado a substituir um fisiologismo tacanho por um reducionismo psicológico também grotesco, mas sim a novamente levantar questões éticas, que se revelam ainda como questões ontológicas e que ajudam a reabilitar a primazia da clínica: o que significa para esse sujeito, em seu drama pessoal e em sua história singular, aquilo que lhe advém como doença ou como cura? Ou ainda: o que fazer por esse sujeito que implora pela reversibilidade do tempo para permanecer atado a uma saúde miticamente perdida ou à idéia de uma doença à qual ele teme ter que renunciar, mesmo que do ponto de vista médico ela tenha se tornado obsoleta? Talvez fosse, nesse sentido, que Canguilhem aproximava a "pedagogia da cura" do conceito freudiano de "prova da realidade"? Uma prova de cura, em suma?

"A morte é certa, mas a hora incerta", diziam os Antigos. Curar, em todos os sentidos do termo, não seria permitir que, para um dado sujeito, pudesse se reabrir uma relação de incerteza quanto a seu futuro, relação que teria sido 


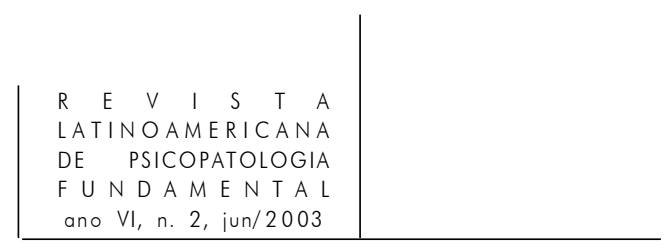

comprometida durante algum tempo pela doença? Se o futuro, como nota JeanLuc Nancy (2001), encontra-se firmemente ligado com a nudez, com esse nu que se esquiva infinitamente por um pouco mais de pensamento e um pouco mais de liberdade, o saber da doença, sua nominação, seu prognóstico, embrulham, oneram, encobrem ao mesmo tempo esse futuro. Também disso é preciso se curar para se reencontrar uma maior liberdade de pensamento e de vida. Curar-se não é então apenas esquecer uma doença que a medicina tratou com sucesso; curar-se é também esquecer o saber que ela proporciona sobre a causa e a hora de sua morte. É, em suma, esquecer a morte para melhor reencontrar o tempo em uma duração em que não se sabe quando e de que se vai morrer. Não é proceder como se o tempo fosse reversível mas, muito pelo contrário, assumir plenamente tal irreversibilidade e novamente abrir o enigma de seu termo, de seu cumprimento, que a doença tinha prematuramente resolvido. Mas para isso, a cura atestada do ponto de vista médico, ainda que necessária, não é suficiente. É preciso ainda que essa cura médica seja acompanhada de uma modificação tal no funcionamento psíquico que sua ocorrência se inscreva numa outra relação do sujeito com seu ser-para-a-morte, que o sujeito renuncie ao saber sobre sua morte, reificada de maneira probabilística em seu cumprimento e sua causa, para se abrir ao não saber de seu ser sobre a morte, à sua própria nudez. Essa modificação das posições psíquicas de um sujeito é necessariamente singular e é nisso que ela exige do médico uma clínica que não ceda nem a respeito de sua tomada de partido metodológico, nem sobre sua ética de ter que acompanhar um sujeito até curá-lo de sua cura.

Em Prometeu, de Ésquilo, o herói não apenas rouba dos deuses o fogo para trazê-lo aos homens. Ele também lhes retira a presciência da hora de sua morte, abrindo-os assim a um futuro indeterminado: "Esse seria seu verdadeiro dom. Antes, os homens teriam passado a vida em cavernas, esperando ociosos e morosos a morte, como tantos outros animais em seus antros. Mas desde que lhes foi retirado o conhecimento da hora de sua morte, a esperança neles renasceu; os homens então despertaram e começaram a transformar seu mundo em um mundo habitável" (Gadamer, 1993, p. 165).

\section{Referências}

BRUn, D. (1989). L'enfant donné pour mort, Enjeux psychiques de la guérison. Paris: Eshel, 2001.

CANGUilhem, G. Essai sur quelques problèmes concernant le normal et le pathologique (1943) seguido de Nouvelles réflexions concernant le normal et le pathologique (1963-66). In: Le normal et le pathologique. Paris: PUF, 1979. 


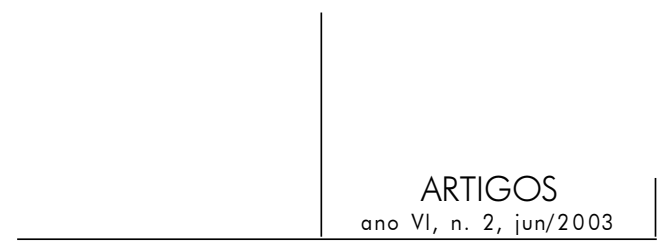

Études d'histoire et de philosophie des sciences. Paris: Vrin, 1989.

Écrits sur la médécine. Paris: Seuil, 2002.

CAnto-Sperber, M. L'inquiétude morale et la vie humaine. Paris: PUF, 2001.

Del Volgo, M.J. L'instant de dire. Le mythe individuel du malade dans la médecine moderne. Toulouse: Érès, 1997.

; Gori, R.; PoInso, Y. Roman de la maladie et travail de formation du symptôme.

Complementarité des approches psychanalytique et médico-biologique. Psychologie Médicale, v. 26, n. 14, p. 1434-8.

FÉrenczi, S. (1933). Confusion de langue entre les adultes et l'enfant. In: Psychanalyse IV. Paris: Payot, 1982, p. 125-35.

Forthomme, B. L'expérience de la guérison. Paris: Seuil, 2002.

Foucault, M. (1974-75). Les anormaux. Cours au Collège de France. Paris: Gallimard le Seuil, 1999.

FreUd, S. (1916-17). La nervosité commune. In: Introduction à la psychanalyse. Paris: Payot, 1961, p. 356-69.

Gadamer, H.-G. (1993). Philosophie de la santé. Paris: Grasset, 1998.

Gaudillière, J. P. Inventer la bio médecine. Paris: La Découverte, 2002.

GoRI, R. Logique des passions. Paris: Denöel, 2002.

ILlich, I. Némésis médicale: l'expropriation de la santé. Paris: Seuil, 1975.

LacAn, J. La place de la psychanalyse en médecine. Conferência de 16 de fevereiro de 1996 por ocasião de uma mesa-redonda do Collège de médecine. Texto original comunicado por Jacques Sédat.

Lagrée, J. Le médecin, le malade et le philosophe. Paris: Bayard, 2002.

LALANDE, A. Vocabulaire technique et critique de la philosophie. Paris: PUF, 1993.

Munnich, A. Des maladies pas comme les autres. In: 4e. Colloque de Pédiatrie et psychanalyse. Techniques médicale et fantasmes. Au nom d'un projet d'enfant parfait, sob a direção de Danièle Brun. Paris: Éditions Études freudiennes, 2001, p. 18-26.

NAnCY, J. L. La pensée dérobée. Paris: Galilée, 2001.

REY, A. (dir.). Dictionnaire historique de la langue française. Paris: Dictionnaires Le Robert, 1992.

Roudinesco, E.; Plon, M. Dictionnaire de la psychanalyse. Paris: Fayard, 2000.

Skrabanek, P. La fin de la médecine à visagem humaine. Paris: O. Jacob, 1995. ; McCormick, J. (1989). Idées folles, idées fausses en médecine. Paris: Odile Jacob, 1997.

SteIn, C. Effet d'offrande, situation de danger. Une dificulté majeure de la psychanalyse. Paris: Éditions Études freudiennes, 1988.

Todorov, T. Mikhäil Bakhtine le principe dialogique seguido de Écrits du Cercle de Bakhtine. Paris: Seuil, 1981.

Zarifian, E. (1994). Des paradis plein la tête. Paris: Odile Jacob, 1998. 


\section{Resumos}

La utilización del concepto de ética en el campo de la salud puede ser deducida de la necesidad de llevar en consideración un resto producido por las nuevas tecnologías discursivas que tratan en nuestra época de la salud, la enfermedad y su tratamiento.

Los progresos espectaculares de los procedimientos técnico-científicos de la medicina, lejos de reducir el alcance del acto de evaluación, amplifican dialécticamente aquello que en ellos se encuentra en juego.

Palabras clave: Ética, prácticas de salud, medicina técnico-científica

Le recours au concept d'éthique dans le champ de la santé, se déduirait de la nécessité de devoir prendre en compte un reste produit par les nouvelles technologies discursives qui traitent à notre époque la santé, la maladie et le soin.

Les progrès spectaculaires des procédures technoscientifiques de la médecine, loin de réduire la portée de l'acte d'évaluation, en augmentent dialectiquement les enjeux.

Mots clés: Éthique, pratiques de santé, médecine technoscientifique

The use of the concept of ethics in the field of health care can be deduced from the need to take into account a remainder produced by new discursive technologies that deal with health, disease and treatment today.

The spectacular advances in techno-scientific medical procedures, far from reducing the extent of acts of evaluation, dialectically increase what is at stake in them.

Key words: Eethics, health practices, techno-scientific medicine

Versão inicial recebida em outubro de 2002

Versão traduzida recebida em abril de 2003 